\title{
Jesus the Galilean
}

\author{
Willem S Vorster \\ University of South Africa
}

\begin{abstract}
Jesus the Galilean

One of the most challenging problems in New Testament research concerns the question, 'Who was Jesus?' In the first part of this essay attention is paid to why there is so much confusion in the answers given to the question. Then the phrase 'Jesus the Galilean' is discussed in an attempt to situate Jesus in a first-century Galilean historical context.
\end{abstract}

The Gospel of Mark relates us this challenging little episode of Jesus and his disciples who were on their way to the villages of Caesarea Philippi when Jesus asked them:

'Tell me, who do the people say I am?' 'Some say that you are John the Baptist', they answered: 'others say that you are Elijah, while others say that you are one of the prophets.' 'What about you?' he asked them. 'Who do you say I am?' Peter answered, 'You are the Messiah.' Then Jesus ordered them, 'Do not tell anyone about me.'

(Mk 8:27-30, TEV)

What followed is known. Even Peter, the closest friend and follower of Jesus apparently had mistaken expectations about Jesus, and according to Mark, did not grasp the significance of what he had just said about the messiahship of Jesus.

After almost twenty centuries of worship, historical study and admiration of Jesus of Nazareth, Christian believers and New Testament scholars alike still

* This essay is a reworked version of the C B Powell public lecture held during February 1990 in Pretoria. 
grapple with the question: Who was Jesus? This is also the issue I would like to address in this series of two essays. Because of the lack of communication between scholars and the believing community, the diverse points of view which are often taken by scholars on different theological issues, the different theologies which presuppose theological answers given to contemporary social and political problems, and the lack of interaction between lay people and the academic community, there seems to be a yawning gulf between scientific research and the beliefs of the man in the street. I do not pretend that a series of two essays can narrow or even get rid of the schism. But I am convinced that, by taking current research and current beliefs seriously, one can contribute to an understanding of the difficulties and challenges involved in the questions of who Jesus was, what his significance was and, most importantly, what his significance is for us today.

I distinguish between 'who Jesus was', and 'what his significance was/is' for the simple reason that who a person is, and what people s.y or think that person is, are often two totally different things. In the case of Jesus it is even more so.

The first essay deals with two issues. It firstly concerns the question of why there seemingly is confusion, if not total chaos, in the answers given to the question of who Jesus was. I shall secondly give attention to the phrase Jesus, the Galilean, by attempting to situate him in a first-century Galilean historical context. This will on the one hand illustrate the importance of understanding Jesus of Nazareth within the geographical area in which he mostly operated and the historical circumstances under which he lived, and on the other prepare the way for the next essay (see HTS 47/2, 1991).

In the second essay I shall develop two possible answers to the question of who Jesus was and also focus on the implications of the points of view that Jesus was either an eschatological prophet or a first-century sage, that is wisdom teacher, or perhaps both. Let me start with the first part of this essay.

\section{WHY SO MANY ANSWERS?}

If I were to ask any lay person, or for that matter any theologian: 'Who was Jesus?' the question would undoubtedly give occasion to a number of different important answers, depending on many things. Some of these answers might even be similar to those reportedly given by the disciples on their way to Caesarea Phillippi. One might say he was the Messiah, while another would argue that he was the Son of God, incarnate. Yet another might maintain that he was the Son of man, and that he will return to judge the sinners and unbelievers at judgement day. It might also be argued that he was the saviour of the world or, in another idiom which is perhaps 
more familiar today, the liberator of the oppressed. Thus we can continue giving possible answers to the question. A number of these possible answers presuppose church dogma and are formulated from the perspective of the time after the resurrection, while others tend to focus on the time before his death. Or to put it differently: some of these answers relate to his significance for certain people while others focus on who he was when he was on earth.

Some two hundred years ago, in 1778 to be precise, seven fragments of a manuscript - in which a scholar of that time had gathered the courage to strip the dogmatic overlayers of the pictures of Jesus painted by the church through the centuries - were published posthumously. I am referring to Reimarus's manuscript Concerning the aims of Jesus and his disciples, published by G E Lessing. This document, however we might judge it, was the birth of the modern quest for the historical Jesus. Being influenced by the Enlightenment, that is, the eighteenthcentury philosophical movement stressing the importance of reason, Reimarus subjected dogmatic beliefs about Jesus, and also the sources from which we know Jesus, to rigorous historical criticism. It soon gave rise to a flood of publications on the question of who Jesus really was. Noticing the differences between the Gospels in terms of what Jesus had said and done, scholars came to realise that the Gospels were not history books in the strict modern sense of the word. The differences and agreements were the result of the way in which the Jesus tradition had been transmitted, and the purposes for which the different Gospels had been written. I shall return to this.

For our purpose we will have to take a short cut through two centuries of historical research. During this time critical attempts were made to save the Jesus who once lived in Palestine from the dogmatic, christological, images which the church painted of him, that is, about his humanity and divinity. The phrase 'historical Jesus' was coined to distinguish 'Jesus of Nazareth', the man of flesh and blood, from the 'Christ of faith' of whom we learn in the New Testament, and whose significance was elaborated upon by the church through the ages. What came about is tremendously interesting and fascinating. Researchers' attempts to save the Jesus of history from the dogmas of the church concerning him, resulted in a variety of contemporaneous (that is, eighteenth- and nineteenth-century pictures) of Jesus. For the rationalists he became a preacher of morals, the idealists regarded him as the prime example of humanity, the aesthetes portrayed him as a genius in the art of rhetoric, while the socialists maintained that he was the friend of the poor and a social reformer (see Jeremias 1961:14).

By the end of the nineteenth (Kähler) and beginning of the twentieth (Schweitzer) centuries, at least some scholars argued that, in spite of the admirable 
motives of their predecessors and fellow New Testament scholars to search for the historical Jesus, one was confronted by the fact that our extant documents were written from the perspective of faith in Jesus, that is, the Christ of faith, and not from the perspective of the historical Jesus. These documents were written long after the events about which they report, and therefore they did not concern the question of who Jesus was, but what his significance was for those who believed in him. It was furthermore asserted that the biblical Christ of faith was what was important for our faith in Jesus, not who he was and what he did. In fact, in certain circles it was even maintained that since it was impossible to go back to the original historical Jesus we would have to satisfy ourselves with the faith of the early Christians about him. As a result for almost half a century there was virtually no quest for the historical Jesus.

Since 1953 there has been renewed interest in the question of who Jesus was, but also into his significance for the early church and for us today. The so-called New Quest has been an attempt to avoid the impression that his humanity was unimportant for faith or, that his earthly life was not as important as the fact that he was resurrected. The term 'historical Jesus' also underwent a redefinition and came to be distinguished from the term 'earthly Jesus'. While the former is being used for the historian's answer to the question of who Jesus was, the latter is used with reference to the flesh and blood Jesus who lived in Palestine at the beginning of the first century $\mathrm{CE}$. The main issue was to determine the exact relationship in terms of continuity between the man Jesus who lived on earth, and beliefs about him as the resurrected Christ. What are the historical links between the man of Nazareth and the Christ of faith?

Of particular interest for the purpose of this essay is the renewed interest of scholars in Jesus the Jew. What do we mean when we say that Jesus was a Jew? If we follow the Gospel tradition and say that he was a Jewish teacher, what do we mean by the term 'teacher'? Or a Jewish prophet? Do our sources afford us sufficient material to say what we mean when we call Jesus a Jewish prophet or rabbi? In view of the complex nature of first-century Jewish Palestine, the groups who lived there, the relationships between them, their relationship with the authorities, that is with the Roman rulers, the interaction between Jews and other inhabitants of the country, and so on, these questions are not of academic interest only. In fact, they concern our concept of the past and of Jesus of Nazareth.

In scholarly circles one finds a great variety of images of Jesus the Jew, relating to the different Jewish backgrounds against which the images are located. The following have been proposed by Christian scholars: an eschatological prophet, a political revolutionary, a magician, a Hillelite or proto-Pharisee, an Essene, a 
Galilean charismatic or a Galilean rabbi. In addition, there are the different Jewish views of Jesus, which add to or complement the variety of views held about his Jewishness. One of the reasons for the many answers to the question of who Jesus was, lies in the lack of sources which would enable us to give a precise description of all the relevant detail. Let us for a moment look at our sources.

I have already referred to the agreements and disagreements between the different Gospels and other documents which report the sayings of Jesus and what he did during his life. This is not the place to deal in detail with the matter, but let us for the sake of illustration return to the Caesarea Philippi incident for a moment. What did Jesus say to his disciples at Caesarea Philippi about carrying their crosses?

'If anyone wants to come with me', he told them, 'he must forget self, carry his cross, and follow me'.

(Mk 8:35, TEV)

or

'If anyone wants to come with me, he must forget self, take up his cross everyday (my italics), and follow me'.

(Lk 9:23, TEV)

Mark is clearly emphasising that Jesus wanted his followers to be prepared to die for his sake and for the sake of his message. Luke, on the other hand, obviously 'spiritualises' the matter by adding 'every day'. This is just one of the minor, but nevertheless important, differences in wording of the sayings of Jesus, illustrating the fact that the Gospels do not necessarily report the sayings of Jesus verbatim. Did he ever have contact with the Samaritans, since only Luke and John report on his visit to Samaria? Why do the travels of Jesus in the Gospel of John differ from those in the other Gospels? How long was his ministry? When was he crucified (see Luke 24:44 and John 19:31)? Why was Jesus crucified? And, who was finally responsible for his death?

These and many other questions arise when one compares the detail of the different Gospels. They also illustrate one of the problems we have in answering who Jesus was. Our sources, both canonical and extracanonical, do not answer the question in a clear-cut manner. We may call the Gospels ancient biographies, but like other contemparory ancient biographies, none of the Gospels can be regarded 
as a life of Jesus where a detailed description is given of his person, life, works and words (see Vorster 1981). And the same holds good for the extracanonical material.

In addition to the lack of sources and the difficulties involved in interpreting ancient documents, our knowledge about the past and the culture in which we live also plays a tremendously important part in the formation of our views about Jesus and his significance. I have already referred to the results of the Old Quest. In addition there is the influence of our theological traditions. It has correctly been observed that six so-called salvation events determine theological predispositions, namely the incarnation of Christ, his death and cross, his resurrection on the third day, his ascension, the outpouring of his Spirit at pentecost, and his second coming or parousia (see Bosch 1986:2). Depending on where one puts the emphasis one would have a different theology and a different image of Jesus. Liberation theologians seem to be interested in a Christ who suffers with the oppressed and knows about their agonies and fears, not in a Christ who only offers eternal salvation. They emphasise the incarnation of Jesus. In the reformed tradition (in South Africa at least), the emphasis is strongly on Christ's act of atonement on the cross and eternal salvation. In the place of a suffering Christology one finds a Christology of atonement and eternal salvation. And in many instances even a Christology of victory. And so we can continue (see Bosch 1986:2-6).

The influence of all these different views on the question of who Jesus was, and his significance, is obvious. Unless there is tolerance for other views and and a willingness to be corrected, Christians will continue to misunderstand each other. The problems are simply implied by the New Testament and its interpretation, and that is why the question of Jesus' identity was is so important for us. We tend to misjudge the role that tradition, culture and circumstance plays in our views.

The quest for the historical Jesus concerns our interest in the past and the attempt to understand those who lived in remote times. It also concerns what we think and believe and one should not too easily say that historical problems such as Jesus' identity do not concern us. On the contrary, we are wittingly and unwittingly informed about the past by all sorts of sources that we simply presuppose. That partly explains our current confusion regarding Jesus and his teaching, and our wish to legitimatise a point of view. Let me shortly elaborate on this. I shall illustrate the problem of interpreting who Jesus was by taking two examples from the Gospels as an aid to understanding why different points of view are taken by different theologians who try to argue on the basis of what is found in the New Testament.

My first example is a very simple one, but it nevertheless illustrates a typical problem we are confronted with in our attempts to say who Jesus was and what he taught. According to Mark 1:17 Jesus called Peter and Andrew and said to them: 
'Come with me, and I will teach you to catch men' (TEV). How should we interpret this short metaphorical saying? Did Jesus mean that Peter and Andrew would become missionaries who would go out and call people to follow Jesus? Or did he have in mind that they would become 'fishers of souls', that is, that they would become people who would gather souls for heaven? It is also possible to argue that Jesus expected the eschatological judgement of God to come soon and that he called Peter and Andrew to help him bring home the people of God without delay (Jeremias 1961:132-13). In what sense can this saying of Jesus be used in a missionary or evangelism context? The particular interpretation chosen would obviously make a difference to one's case and how one argues it.

Let us take another example. According to the Gospels Jesus 'cleansed' the temple. But, why would he have done that (Mark 11:15-19 and parallels)? Some interpreters think that the 'cleansing' refers to prior profanation and that Jesus wanted to purify the temple to fulfil its intended purpose. Others argue that it refers to the rejection of the Jewish cult by the early church, or that it shows the power of the resurrected Christ. It is also maintained that the 'cleansing' was a symbolic or prophetic sign which was intended to cause the repentance of Israel (see Sanders 1985:61-62). Be it as it may, one thing becomes clear - and that is that our views about who Jesus was play a significant role in our interpretation of the deeds and words of Jesus. If we regard Jesus as a religious reformer, we will argue that the first interpretation (purification) is correct. If we think that he was an eschatological prophet we might go for the symbolic interpretation. Let us get a little closer to the problems caused by present-day views in South Africa about Jesus.

For a variety of good reasons many recent public debates in South Africa - in which Christian religion and, in particular, Jesus' views played a role - concentrated on political matters such as violence. How should we regard the following saying of Jesus with regard to violence and oppression?

You have heard that it was said, 'An eye for an eye, and a tooth for a tooth.' But now I tell you: do not take revenge on someone who wrongs you. If anyone slaps you on the right cheek, let him slap your left cheek too. And if someone takes you to court to sue you for your shirt, let him have your coat as well. And if one of the occupation troops forces you to carry his pack one kilometre, carry it two kilometres ....

(Mt 5:38-41, TEV) 
Is this a plea from the side of Jesus for total submission, passivity or passive resistance? (See Wink 1987.) Obviously one cannot make out a case for any of these answers without taking a large amount of other material into account. But it also underscores the great danger of taking these first-century words out of their context and of simply applying them to our own complicated situation. Unfortunately this is what so often happens, at the risk of making illegitimate cultural and religious transfers in order to have Jesus on one's side, so to speak.

The problem of the historical Jesus teaches us one thing in particular, and that is that Jesus lived in a far distant time in a situation totally different from ours. In spite of all the positive things we can say about the history of Christian doctrine on Jesus, we also immediately have to recognise that our views are contaminated by the distance in time and the minds of men. All theologians and lay Christian believers can learn one thing from the historical Jesus problem, which is that their views on who Jesus is or was are their own. Unless these views are scrutinised by rigorous historical criticism they are nothing more than modern men's images of Jesus. It is only in a context of interaction and negotiation that we can work out probable answers to who Jesus was and what his views were on particular issues of his time.

Let me summarise. Because of the nature of our sources about Jesus - the fact that they are limited, that they lived in a totally different time and culture from our own - and the fact that we stand in a particular tradition, there is a great need for us to get to know the past better and to be moderate and tolerant in our views about Jesus and his significance for today. This is one of a number of reasons why there is such a lively interest in who Jesus was in New Testament scholarship today. Having clarified the problem, in the next part of the essay I will concentrate on the phrase Jesus the Galilean, in order to place Jesus in a possible historical context.

\section{JESUS THE GALILEAN}

New Testament scholars agree about a relatively small number of so-called 'facts' in the life of Jesus. The following are taken as indisputable: (1) Jesus was baptised by John the Baptist; (2) He was a Galilean who preached and healed; (3) He called disciples and spoke of there being twelve; (4) He confined his activity to Israel; (5) He engaged in a controversy about the temple; (6) He was crucified outside Jerusalem by Jewish authorities; (7) After his death his followers continued as an identifiable movement; (8) At least some Jews persecuted parts of the new movement, and it appears that this persecution endured at least to a time near the end of Jesus' career (see Sanders 1985:11). 
We have already noted that there is no such thing as a bare fact in the history of Jesus research. Even the indisputable facts have to be interpreted. So, if we say that Jesus was a Galilean who preached and healed, we at least have to say what we mean by 'Galilean', 'preaching', and 'healing' in first-century Palestine. We shall, however, for the purpose of this essay concentrate on 'Jesus the Galilean'. Time and space do not allow us to go into detail, but a few remarks are necessary. I shall concentrate on the territory, its inhabitants, the relationship between urban and rural Galilee, and the social situation of Galilee in the time of Jesus.

The general picture of Jesus and his first followers is one of a group of rural, illiterate people who travelled around in Galilee while Jesus preached and healed people. Since the geographical environment of people helps to shape their identity, it is necessary to know what Galilee refers to and who inhabited the area, to test the validity of such a supposition.

The term 'Galilee' means 'circle', which refers to the geographical shape of the area it covers. In the time of Jesus it consisted of Upper and Lower Galilee in the north and south respectively, and the Valley running along the Jordan. As in the rest of Palestine, there is a coastal strip between the Mediterranean Sea and the central hilly area, with a valley on the Eastern side along the Jordan River, north and south of the Sea of Galilee. Galilee is characterised by its mountain ranges and fertile valleys. Unlike other parts of the country, Galilee had a substantial rainfall, making it an important agricultural area, the most productive region of the country. It produced most of the produce used in the ancient world. In addition to wheat and grain, the vine and the olive grew in abundance. From ancient export catalogues we know of items such as grain, oil, wine, different kinds of vegetables and herbs that were exported from Galilee and Syria to Egypt (see Freyne 1980:172). Because of its location, the network of roads, and the closeness to the ports of Sidon, Tyre and Ptolemais, Galilee was one of the most important importers and exporters in the Near East.

The fishing and glass industry were the two most developed industries in Galilee. Fishing rights on the shores of the Sea of Galilee were farmed out at a high price, and methods of preservation and marketing were developed to improve export (Freyne 1980:174). The glass-making industry was developed in Hellenistic times (first century BCE). The plain of Acco on the border of Galilee provided the raw material for the glass (Freyne 1980:175).

It is remarkable that the ministry of Jesus is related to villages such as Nazareth, Capernaum and others, while large cities such as Sepphoris and Scythopolis are not mentioned. One should not infer from the absence of any mention of these cities in the New Testament that there were no large cities at that time, or that Jesus and his 
followers were unacquainted with urban life and practices. Sepphoris, Tiberias and Scythopolis were within walking distance of Nazareth and Capernaum. In fact, Sepphoris was less than five kilometres from Nazareth, where Jesus spent his youth and learnt to be a carpenter. Before we come to urbanisation and the social status of people in the region, let us pay attention to the people who lived in Galilee.

Galilee was known as 'Galilee of the Gentiles' (see 1 Macc 5:15) in the second century BCE, thus expressing the feelings of the Jews who lived there. This remained the situation for many centuries. When Alexander the Great, a Greek from Macedonia, defeated Darius, king of the Persians, and his armies at Issus in 333, Galilee was still part of the Orient. The situation was soon changed when a successor of Alexander, namely Ptolemy I of Egypt, conquered Palestine and the country became part and parcel of the Hellenistic world. Occupation forces settled in the country, including in Galilee, land ownership changed and the people of Israel were subjected to the influences of the Greek way of life. Many of the Jews, especially members of the urban upper class - including members of the priesthood of the temple - supported Hellenisation. There was, however, a large number who rejected, and even fought against any form of Hellenisation. From then on until the middle of the first century BCE, when the Romans conquered Palestine in 63, the region was unstable and there were constant uprising and unrest. The influential Jewish Maccabean family (the Hasmoneans) led the revolt against the oppressors when Antiochus Epiphanes IV, the Seleucid King of Syria tyrannically suppressed Judaism and profaned the temple in Jerusalem. During the period 167-63 BCE the country was ruled by the Maccabees. They repossessed a great part of the country, including the greater part of Jerusalem. During that period Sepphoris was the administrative centre in Galilee. In 63 BCE Pompey's legions captured Jerusalem and Palestine became part of the Roman empire (see Freyne 1980:22ff).

Jewish settlement in Galilee followed the Maccabean revolt in 164. Pompey, however, recaptured many of the cities and incorporated them into the Roman administration. Herod the Great made Galilee and Perea part of the Roman province of Judea but, after his death, Galilee and Perea became part of the tetrachy of Herod Antipas.

By this time Galilee was greatly Hellenised, both politically and socially. The region was ruled and administered in a Roman manner, including trade, tax and infrastructure. Although Aramaic, the lingua franca of the Persian Empire, was still spoken by most Jews, and Hebrew was probably still in use, Greek was the language used in the market-place. It can be assumed that most Jews, including Jesus and his followers, were to a greater or lesser extent bilingual, and could also speak Greek. Latin was the language of the rulers and the military but in most cases these people 
could also speak Greek and knew the Greek way of life. Galilee was correctly referred to as Galilee of the Gentiles. The region was inhabited by others beside the Jews and these Jews were no longer free from the influences of a cosmopolitan society even though some of them rejected the Hellenistic way of life. Obviously it was socially, economically and politically that the Jews of Galilee were most influenced in the Hellenistic period. They were allowed to practice their religion and worship their God.

One of the aspects which greatly influences one's image of Jesus and his first followers is the relationship between the cities and the smaller villages and towns. Although it is almost impossible to say what the exact relationship would have been between Sepphoris and Nazareth, for instance, one can get a rough picture of the influences that cities in the days of Jesus had on the general population of Galilee.

According to the Jewish contemporary historian, Josephus, who also was a leader of a revolt in Galilee against Rome in $66 \mathrm{CE}$, there were no less than two hundred and four villages in the whole of Galilee (Jos Vit 45:235). This is quite a number for a region as small in size as Galilee. Capernaum apparently was a large village with a population of ten to twelve thousand (see Overman 1988:162). It was a fishing village similar to other villages on the shore of the Sea of Galilee. The towns and villages which Jesus visited according to the New Testament are all within walking distance, and in the proximity of large cities. This was made possible by the network of roads and routes which were necessary for trade.

One of the most important cities was the capital of Galilee, namely Sepphoris. According to Josephus (Vita 45:231 \& 9) who is one of our main informants in this regard, it was the largest city in Galilee, and the seat of the royal bank and archives. Archaeological evidence furthermore shows that 'there were courts, a fortress, a theatre seating three to four thousand people, a palace, a colonnaded street on top of the acropolis, two city walls, two markets (upper and lower)...and the arsenal' (see Overman 1988:164). In addition there were cities such as Scythopolis and Tiberias with similar building constructions and features of ancient cities, such as water systems and aqueducts. In Magdala (Tariceae), a city with a population of forty thousand (Jos $B J$ 2:608), there was even a hippodrome, or an arena.

When and how often Jesus and his followers visited these cities is not known. What is, however, clear from the urban imagery of the Gospels and specifically the teaching of Jesus, is that they were acquainted with city life. Overman is correct in saying that: 'One could not live in any village in lower Galilee and escape the effects and the ramifications of urbanization.... These lower Galilean cities functioned as regional centers of Roman power and culture and would have been unavoidable in this small area in terms of their influence and impact' (Overman 1988:165). 
Although the Gospels depict the activities of Jesus in the region of Sepphoris, that is, the villages of Nazareth, Cana and Nain, and the area of the western shore of the Sea of Galilee, these activities presuppose a setting which includes urban centres as an integral part. In his teaching Jesus refers to courts, the market-place, financial investment which earns interest, the absence of a landlord, images which indicate that he was familiar with city life. One also has to remember that agriculture 'in the Roman empire was intimately connected with urban environments' (Edwards 1988:170) and that commerce made the movements of Jesus to the coastal area of Sidon and Tyre, the villages of Caesarea Philippi and the cities of the Decapolis, possible. It was in an environment of cities that Jesus operated because of the market and commercial networks. Import and export networks also played a role.

The broad sweep of Galilee's import network is indicated by a host of items including Babylonian beer, medium beer, Egyptian barley beer, smoked fish/lentils from Egypt, cheese from Bythinia, mackerel from Spain, wines, asses from Lydia, purple dye from Tyre, jewelry from Egypt (as well as parchment and papyrus).

(Edwards 1988:175)

It is within this context that we have to imagine the activities of Jesus. The specific rural and agricultural aspects of his activities and teaching are embedded into the highly urbanised and commercial setting of Galilee in the first century CE. Jesus was not unaware of the people who lived in the cities and who administered the country. Other important matters are how society was structured and who played which roles.

In the Gospel tradition the peasants made up the bulk of the population. They were obviously of the lower class. Like the peasants, the artisan class (of which Jesus, Paul, and the fishermen were members) was also part of the lower class who lacked of power. They were not indigent, but as a class in society they did not have power and influence except in their own circles (see Saldarini 1988:201). The poor, and the bandits (some of whom lived in caves in the mountainous areas of Galilee), also belonged to this group of society.

The governing class was very small. According to Saldarini (1988:200) perhaps one to two percent of the population formed part of this upper class. It was made up of both hereditary aristocrats and appointed bureaucrats (Saldarini 1988:200). They owned the land and controlled the political power and wealth in the region. Through taxation, confiscation, and the selling of offices they acquired wealth and 
influence.

Another important group in the society was the so-called retainer class:

The retainer class, perhaps $5 \%$ of the population, served the needs of the ruler and the governing class. To some extent they shared in the life of the elite, but not in its direct power. Soldiers, bureaucratic government officials, various kinds of servants, religious leaders, and educators were all necessary for the functioning of society, and as a group they had a great impact on society and culture.

(Saldarini 1988:201)

The most important people in this group for our purpose are the Pharisees and the scribes. We get to know them as religious opponents of Jesus in the Gospels and tend to forget that we do not know exactly how the Pharisees earned their daily bread. That is why we think of them only in their roles as religious leaders. But how did Jesus and his followers experience them as members of the retainer group in society, serving the interests of the upper class? The scribes were obviously people of learning who could read and write and would have been archivists, secretaries, and so on in the administration of the Roman Empire.

This is not the place to go into a detailed analysis of possible conflict concerning power between the upper and the lower classes. It is difficult to say exactly how revolutionary Galilee was at the time of Jesus because of the lack of evidence, and because any information about the revolutionary situation before the Jewish/ Roman War is read into the period (e $\mathrm{g}$ for that concerning the Zealots, see Horsley 1988:184). Obviously there would have been tension (see Freyne 1980:208ff). Perhaps economic pressure and the problem of foreign rulers could have given rise to messianic and apocalyptic hopes among the lower class. Evidence, however, is lacking. It is nevertheless possible that Jesus of Nazareth could have been understood as an opponent of the status quo, not to speak of as a rebel. Whatever the historical value of the Caesarea Philippi event, it is possible that some of his followers would have seen him as a messianic figure. The fact that he specifically mixed with the lower class and preached his message to them makes it possible that, even though it was not necessarily his intention, some would have regarded him as a leader of the have-nots.

The peasants and the fishermen alike were heavily taxed. In addition to the secular tax they had to pay to the state they were also obliged to pay a religious tax since tithing was regarded as compulsory. One can even talk of a 'rural proletariat'. 
This is clear from the Gospels where we read of day labourers (Mt 20:1-16), hired servants (Mk 1:20), vineyard workers (Mk 12:1-10), beggars (Lk 16:6), and fishermen who worked all night without success (Lk 5:11).

The foregoing gives us a rough picture of the situation in which Jesus operated. It is too early to answer the question of who Jesus was. However, we can already place him within a concrete historical situation, namely that of Galilee of the early first century. Being a member of the lower class of a society who had to labour for their daily bread in the most beautiful part of Palestine, somebody who had an openness towards the sufferings of the majority of the people, and a religious Jew with a message, he could have been interpreted from many different perspectives by his followers and his contemporaries, as well as by the members of the upper class and the retainer class when they became aware of his activities and what he had to say. He also must have been well informed as far as other persons with 'a message' in Galilee were concerned. As in other places in the Hellenistic world there were many different people, each with their own philosophy of life. Whether he had heard popular philosophers and itinerant teachers is not known, but it is possible. In any case the picture of Jesus and his early followers as a group of rural, and perhaps even uninformed people, seems to me improbable. It has become clear that they must have been subjected to and informed by the situation in which they lived - that is, a small region, fifty by twenty four kilometres in size, with a highly developed system of trade and commerce.

In the next essay (see HTS $47 / 2,1991$ ) I shall continue my construction of Jesus the Galilean and concentrate on the two possible images: Jesus the eschatological prophet and Jesus the Jewish sage.

\section{Work cited}

Batdorf, I W 1984. Interpreting Jesus since Bultmann: Selected paradigms and their hermeneutic matrix, in SBL 1984 seminar papers, 187-215. Chico: Scholars Press.

Bosch, D J 1986. Dissension among Christians: How do we handle contentious issues? in De Villiers, P G R (ed), Healing in the name of God, 1-8. Pretoria: UNISA.

Downing, F G 1987. The social contexts of Jesus the teacher: Construction or reconstruction. NTS 33, 439-451.

Edwards, D R 1988. First century urban/rural relations in lower Galilee: Exploring the archaeological and literary evidence, in SBL 1988 seminar papers, 169-182. Atlanta: Scholars Press. 
Freyne, S 1980. Galilee: From Alexander the Great to Hadrian 323 B C E to 135 CE. A study of second temple Judaism. Wilmington: Michael Glazier.

Harrington, D J 1987a. The Jewishness of Jesus. Bible Review 3, 32-41.

.-- 1987b. The Jewishness of Jesus: Facing some problems. CBQ 49, 1-13.

Harvey, V A 1967. The historian and the believer: The morality of historical knowledge and Christian belief. London:SCM.

Horsley, R 1988. Bandits, messiahs, and longshoremen: Popular unrest in Galilee around the time of Jesus, in SBL 1988 seminar papers, 182-199. Atlanta: Scholars Press.

Jeremias, J 1961. Der gegenwărtige Stand der Debatte um das Problem des historischen Jesus, in Ristow, H \& Matthiae, K (Hrsg), Der historische Jesus und der kerygmatische Christus: Beiträge zum Christusverständnis in Forschung und Verkündigung. Berlin: Evangelische Verlagsanstalt.

Käsemann, E 1954. Das Problem des historischen Jesus. ZThK 51, 125-153.

Overman, J A 1988. Who were the first urban Christians? Urbanization in the first century, in SBL 1988 seminar papers, 160-168. Atlanta: Scholars Press.

Robinson, J M 1983. A new quest for the historical Jesus and other essays. Philadelphia: Fortress.

Safrai, S \& Stern, M (eds) 1976. The Jewish people in the first century, section 1, vol 2: Historical geography, political history, social, cultural and religious life and institutions. Assen: Van Gorcum. (Compendium rerum Iudaicarum ad Novum Testamentum.)

Saldarini, A J 1988. Political and social roles of the Pharisees and scribes in Galilee, in SBL 1988 seminar papers, 200-209. Atlanta: Scholars Press.

Sanders, E P 1985. Jesus and Judaism. Philadelphia: Fortress.

Schweitzer, A 1966. Geschichte der Leben-Jesu Forschung, 2 vols. München: Siebenstern Taschenbuch.

Vorster, W S 1981. Wat is 'n Evangelie? Pretoria: NGKB.

Wink, W 1987. Jesus' third way. The relevance of nonviolence in South Africa today. Johannesburg: The SACC. 